\title{
Location of Diaspora in V.S. Naipaul's \\ A Bend in the River
}

- Dr. Sanjay Kumar Mishra ${ }^{1}$

\section{Abstract}

The paper explores the traumatic experiences of diaspora in $V$. S. Naipaul's $A$ Bend in the River. It shows how immigrants turn vulnerable in a newly decolonized world. It argues that people suffer from identity crisis when they are culturally and geographically alienated. Identity is inextricably bound up with the notion of location. It analyses the traumatic experiences of diaspora problem of making identity, finding and making location are revealed through Naipaul's writing. It brings to light the expression of identity in diaspora belonging and alienation diaspora, exile, dislocation and displacement.

\section{Key Words}

Diaspora, identity crisis, alienation, decolonization and neo-colonization.

Set in a nameless African country and governed by Big Man, V. S. Naipaul's $A$ Bend in the River shows contradictions in postcolonial world from the point of view of diaspora. The story takes place in a town at the bend of a river in a newly-independent African nation which has just escaped British's domination, and is narrated by Salim, the main character. Salim, whose family migrated to Africa from Gujrat, India in the distant past, finds himself in identity crisis after the nation gains independence from the European colonizers and neocolonized by Big Man, the native African. On pretext of nationalization, Big Man, President of the state confiscates the property of foreign immigrants and render it to the local trustee. Salim turns an alien in his own country and finds himself without home:

Africa was my home, had been the home of my family for centuries. But we come from the east coast, and that made the difference. The Coast was not truly African. It was an Arab-Indian Persian-Portuguese place, and we who lived there were really people of the Indian Ocean. True Africa was at our back ... But we could no longer say that we were Arabians or Indians of Persians; when we compared ourselves with these people, we felt like people of Africa. (12)

Salim, being the allegorical representation of diasporic characters, depicts the identity crisis the immigrants face in post-independent Africa: "I had to break away. I

1 Associate Professor of English, Patan Multiple Campus, TU, Nepal 
couldn't protect anyone; no one could protect me. We couldn't protect ourselves; we could only in various ways hide from the truth" (22). Salim's identity crisis and dilemma reflect the crisis of other immigrants living in Africa.

The novel presents Salim allegorically as the representative of the diasporic people living in Africa, and fits to the category of what Jameson (1987) refers to the "third world" novels: "All Third World cultural texts are necessarily allegorical and this is a very specific way; they are to be read as what I will call national allegories . . . particularly when their forms develop out of essentially Western machineries of representation, such as the novel" (141). The nameless state stands for the post-colonized third world countries which face the dilemma of choosing between their devasted present and traditional past. Bruce King urges: "The namelessness of the country makes it stand for most of the Third World countries which are faced with the dilemma of choosing between their present and their traditional past" (3). The novel is essentially a national allegory as it portrays Salim's life that reflects the story of a nation in a historical moment of crisis.

Salim's analysis of his own situation is the predicament of the expatriates: "I will inherit no house, and no house that I bulid now will pass to my childen ... But home was hardly a place I could rerurn to. Home was something in my head. It was something I had lost" (107). The expatriates lose their identity in the adopted land. They get alienated from both the land of origin and migration.

Big Man's radical nationalization shatters Salim. His business is ceased by the government and given away to an African. Metty informs Salim: "You don't have anything. They take away your shop. They give it to Citizen Theotime. The President made a speech a fortnight back. He said he was radicalizing and taking away everything from everybody. From all foreigners ... You don't have anything, I don't have anything” (299).

As Salim is not a genuine African, he has no place in Africa. He discovers that "the free-for-all of independence has come to an end" (87). His reflection on his postindependent condition stands for the position of immigrants in the transitional phase in the adopted land: "I was waiting for some illumination to come to me. To guide me to the good place and the life I was still waiting for ... But I knew it wasn't like that, really, I knew that for us the world was no longer as safe as that" (110). Salim's reflection on his condition shows the state of post-independent immigrants in the adopted land: "I was waiting for some illumination to come to me. To guide me to the good place and the life I was still waiting for . . . but I knew that it wasn't like that, really, I knew that for us the world was no longer as safe as that" (110).

The measures taken by Big Man and his associates - the national bourgeoisiedevelop sense of insecurity in all the immigrants whose personal lives are redefined by the ongoing tribal conflicts, chaos, and political instability. Frederick Jameson argues that 
"third world national allegory criticizes the national bourgeoisie who is responsible for the failure of national independence" (140). The national bourgeoisie or middle class refers to a group of native intellectuals, businessmen and political leaders who replace the previous colonial rulers after decolonization and turn the neo-colonizers in pursuit of power and money. The main objective neo-colonizers is not the welfare of the newly freed country and its people but they try to replace the colonial rulers and become rulers in their place. Franz Fanon states:

The psychology of the national bourgeoisie is that of the business man, is that of a captain of industry and it is only too true that the greed of the settlers and the systems if embargoes set up by colonialism have hardly left them another choice ... with the national bourgeoisie comes the decline of morals, the installing of corruption within the country, economic regression, and the immediate disaster of an antidemocratic regime depending on force and intimidation. (1579-1586)

Big Man allegorically represents the national bourgeois dictator whose aim is not the welfare of the country, but to replace the white colonial rulers. Salim sees no future for Africa under Big Man's rule: "I saw a disordered future for the country. no one was going to be secure here; no man of the country was to be envied" (118). The nationalization campaign of Big Man includes both the mission of uprooting the migrants from African territory and producing the "New African Men." Ferdinand and other Lycee boys represent the New African Men: "Ferdinand and his friends . . . were young men . . . who would soon become administrative cadets in the capital, serving the President . . . in the Domain they were in presence of foreigners who had a high idea of the new Africa" (138-139). The African Young men are trained by Big Man so that they can lead the future Africa.

Big Man divides the state into two distinct cultures - rural and urban. On the one hand he is building up domain in the city where the traditional African culture has no space and European culture is dominant. He does not make any effort to balance between the past and the present, the traditional and the modern:

Domain was the Big Man's doing ... Everything the President did had a reason. As a result in what was potentially hostile territory, he was creating an area where he and his flag were supreme. As an African, he was building a new town on the site of what had been a rich European suburb ... he was creating modern Africa, he was creating a miracle that would astound the rest of the world. He was bypassing real Africa, the difficult Africa of bush and villages, and creating something that would match anything that existed in European countries. (115-116) 
Power shifts from colonizers to neocolonizers. The impact of the Western colonial powers can be still felt in decolonized territory in name of neocolonialism that gets established by the natives who rise to power. Patrick Williams and Laura Chrisman argue: "This continuing Western influence, located in flexible combinations of the economic, the military, and the ideological is called neocolonialism which is another manifestation of imperialism" (3).

Being an Indian dispora in Africa, Salim feels insecure and threatened in the postcolonial Africa. Salim realizes that he should depend on himself in order to find his own way. He does not accept the role of fate in his life: "I could be master of my fate only if I stood alone. I could no longer submit to fate. My wish was not to be good in the way of our traditions but to make good" (20). Salim feels social insecurity being an African but not a genuine African: "Africa was my homeland... had been home of my family for centuries. But we came from the east coast and that had made the difference" (10).

Salim tries to locate his position with the means of association and dissociation in the adopted country. He sees that culturally Europeans are superior and Africans are inferior. He finds himself in between Europeans and Africans. He is aware that Zabeth has chosen him to teach her son because he knows English and her son can learn manners from him:

If Zabeth chose me for this job it wasn't only because I was a business associate she had grown to trust. It was also because I was a foreigner and English-speaking as well someone from whom Ferdinand could learn manners and the ways of outside world. I was someone with whom Ferdinand could practice. (36)

Salim identifies himself neither with the religion and customs of his relatives nor with those of the Africans of post-independence era. $\mathrm{He}$ fears that the position of diaspora is vulnerable: "Another tide of history was coming to wash us away" (20). Salim takes what seems to be his own opportunity to survive as an individual: "I could be master of my fate if I stood alone" (20). Salim's most appealing quality is his uncompromising quest for his position and persistence to create a new life in the ruins left by violence and anarchy. Salim starts his existential quest to recreate an identity and a sense of security for himself. Salim's psychological trauma becomes apparent when he utters in deep anguish that "Africa is a prison for me" (21).

Besides Salim, Indar, an Indian immigrant also faces the existential identity. He leaves his ancestral home in search of a promising prospect in the West. He wants to "trample past" (157) and look forward to a bright future, denying his identity of being 
an Indian or an African. But he returns to the nameless state as a complete failure as he is marked as "a man of two worlds ... [Africa and India]" (171) that makes him unfit for the job of a diplomat. The historical tide of migration, colonization, independence and racial segregation has changed Indar's life and he confides in Salim that it is not possible to deny history as it is ever present in the life of an individual. All the immigrants suffer from insecurity and perpetual homelessness, as Big Man's "nationalization” (p. 32) has marked them as outsiders who can no longer consider Africa as their home. Indar's comment "I carry the world within me" (175) signifies the perpetual homelessness of diasporic people. Nazruddin, another Indian immigrant is always on move from one place to another in search of a home. At first he leaves the coastal town and moves to Uganda, then to London and finally to America: "Home was hardly a place we could return to. Home was something in our head. It was something we had lost" (124).

Like Salim, Indar is also not genuinely African. He is an Indian by descent and Hindu by religion: "His grandfather had come from Punjab in India to work on the railway as a contract labourer" (17). He returns to the nameless African country after completing his studies in London. His ideas regarding the past are radical: "We have to Learn to trample on the past . . . it isn't easy to turn your back on the past" (141). Indar belives that the Third world people are inferior to the Europeans, and are incapable of understanding the world:

[. . . How incapable we had become of understanding the outside world. We have no means of understanding a fraction of the thought and science and philosophy and law that have gone to make that outside World . . . It never occurs to law that we might make some contributions to it ourselves . .. using the little half skill I have picked up half-knowledge of other men's books. (142-43)

Indar alienates himself from the Third world people and assimilates himself with the West: "For someone like me there was only one civilization and one place-London or a place like it. Every other kind of life was make believe. Home- - what for? To bow our great men?" (151-52). He hates being connected with the leaders of his ancestral land.. He makes his own value: "Tell them that my value is the value I place on myself" (157). For him, home is a make believe, and he rejects the role of any external factor in his identity. He feels castrated by relating himself with Gandhi and Nehru: "We solace ourselves with that idea of great men of our tribes the Gandhi and the Nehru and we castrate ourselves" (152). He despises both the leaders of India: "I studies that large framed photographs of Gandhi and Nehru and wondered how out of squalor like this those men had managed to get themselves considered as men" (148). However, his efforts to be a self-made man in the adopted country turn futile: "As soon as I got there I knew my errand was fruitless. The committee was meant to put English boys in English jobs it wasn't meant for me" (143). His further attempt to have place in the world by becoming an international adviser on the 
Third problem is hindered when he confronts with wealthy Americans in New York:

Indar went to America to New York. He stayed in an expensive hotel. He saw his American people. They were all very nice. But he didn't like the direction in which they were pushing him towards smaller things and he pretended not to notice . . . in New York you drop fast he said. (242)

Indar gets disillusioned, and see the solutions to return home:

It is time for him to go home. There is a dream village in his head. In between he does the lowest kind of job. He knows he is equipped for better things but he doesn't want to do them ... He doesn't want to risk anything again. (244)

Intimidated by African nationalism and political disorder, Naipaul's diasporic characters are afraid of being made homeless. Home, according to Madan Sarup, is "a shelter which guards against the rapid changes one cannot control" (94). However, the physical structure of a house can no longer guard the immigrants against the rapid changes that they cannot control. Salim, though having lived in East Africa since his family migrated from Gujarat in the distant past, is not recognized as an African. His disclosure of the lack of his national identity illustrates the complicated meaning of home. Eric Simpson and George Robertson state that the notion of home is built in the basic pattern of select exclusions and inclusions, which "are grounded in a learned sense of a kinship that is extended to those who are perceived as sharing the same blood, race, class, gender, or relation" (9). Brought in the diasporic context, the immigrants become vulnerable because of unequal power relations generated by the emergent national identity defined by Big Man's government. The redefined the identity of Africans is a threat to immigrants who desire for a nation of their own so as to protect them. However, most of them have no choice but to continue with their life at the mercy of Africans as Salim states: "In our family house when I was a child I never heard a discussion about our future or the future of the coast. The assumption seemed to be that things would continue, that marriages would continue to be arranged between approved parties that trade and business would go on, that Africa would be for us as it had been" (17).

Diaspora is an emotional state of being split between two geographical and cultural domains, and is a struggle of the immigrants between dislocation and location. Salman Rushdie highlights the melancholy of being an expatriate: "Exiles or immigrants or expatriates are haunted by some of loss, some urge to reclaim, to work back, even at the risk of being mutated into pillars of salt" (34). The question of identity is a controversial issue that exists in postcolonial communities due to the circumstances of post-colonial era. Kobena Mercer opines that "identity only becomes an issue when it is in crisis, when something assumed to be fixed, coherent and stable is displaced by the experience of doubt and uncertainty" (43). 
Thus, the narrative highlights the predicament and location of expatriates who suffer being split in their self in the Third World during transitional post-independent period. It shows the multifaceted experiences of a postcolonial world by dealing with contemporary human problems such as disintegration of values, social institutions, family relationships and existential identity problems of vulnerable diasporic population. It points out that people in diaspora do not feel secure in the adopted land. It reveals the traumatic experience of expatriates in the Third World in transitional post independent period. It argues that culture is the source of identity. It is also the source of binding and dividing people. People belonging to the same nation cannot feel being the citizen of their own state when it is in the matter of cultural difference. So, in a way, these migrant people, expatriate or exile, become homeless or citizen of no state. In spite of being licensed with citizenship, Salim and Indar are not welcomed and treated equally as the original or genuine citizen of the state. They are harassed and exploited under different names because of their cultural difference. Salim is exploited under the name of so called nationalization process. His property is confiscated and, he, together with other expatriates, finds his marginalized position in the diaspora and his location quite insecure.

\section{Works Cited}

Fanon, Franz. "Pitfalls of National Consciousness." The Norton Anthology of Theory and Criticism. Eds. Vincent Leitch, and William Cain. New York: W.W. Norton \& Company Inc., 2001: 1778-1783. Print.

Jameson, Frederick. "World Literature in an Age of Multinational Capitalism." Cross Currents in Criticism: Essays on the Present and Future of Literary Theory. Eds. Clayton Koelb, and Vigil Lokke. Indiana: Purdue UP. 1987: 139-158. Print.

King, Bruce. V. S. Naipaul. New York: St. Martin's Press, 1993. Print.

Naipaul, V. S.. A Bend in the River. New York: Penguin, 1979. Print.

Rushdie, Rushdie. Imaginary Homelands: Essays and Criticism. London: Granta Books, 1981. Print.

Sarup, Madan. (1994). Home and Identity from Travelers Tales: Narratives of Home and Displacement. London: Routledge, 1994. Print.

Simpson, Eric, and George Robertson. Dunfemine through Time. The Hill, Merrywalks: Amberley Publishers, 2012. Print.

Mercer, Kobena. "Welcome to the Jungle: Identity and Diversity in Postmodern Politics." Identity: Community, Culture and Difference. Ed. Jonathan Rutherford. London: Lawrence \& Wishart, 1995: 40-65. Print.

Williams, Patrick, and Chrisman, Laura. Colonial Discourse and Post-colonial Theory: A Reader. Cambridge: Wheatsheaf, 1993. Print. 
